\title{
Statistical analysis of Landslide in South district, Sikkim, India: using Remote Sensing and GIS
}

\author{
${ }^{1}$ M. S. Rawat, ${ }^{2}$ B.S.Rawat, ${ }^{3}$ V. Joshi and ${ }^{1}$ M.M.Kimothi \\ ${ }^{1}$ Uttarakhand Space Application Centre Dehradun, Uttarakhand, ${ }^{2}$ D.B.S.PG College, Dehradun, \\ ${ }^{3}$ G.G.S.Indraprasth University, Delhi
}

\begin{abstract}
Landslides are among the most costly and damaging natural hazards in mountainous region, triggered mainly under the influence of earthquakes and/or rainfall. In the present study, Landslide Hazard Zonation (LHZ) of South district, Sikkim State was carried out using Remote Sensing and Geographic Information System (GIS). Various thematic layers namely slope, photo-lineament buffer, thrust buffer, relative relief map, geology and land use / land cover map were generated using remote sensing data and GIS. The weighting rating system based on the relative importance of various causative factors as derived from remotely sensed data and other thematic maps were used for the LHZ. The different classes of thematic layers were assigned the corresponding rating value as attribute information in the GIS and an "attribute map" was generated for each data layer. Each class within a thematic layer was assigned an ordinal rating from 0 to 9. Summation of these attribute maps were then multiplied by the corresponding weights to yield the Landslide Hazard Index (LHI) for each cell. Using trial and error method the weight-rating values have been re-adjusted. A LHZ map was prepared showing the five zones, namely "very low hazard", "low hazard", "moderate hazard", "high hazard" and "very high hazard" by using the "slicing" operation.
\end{abstract}

Keywords: Landslide, RS and GIS, Hazards, Thematic layers, Trial and Error, Sikkim State

\section{Introduction:}

Indian Himalayan Region (IHR) has one of the most rugged mountain topography in the Himalaya, which is geologically one of the youngest mountain range in the world and geologically still active, with vast wealth of natural resources. IHR occupies $18 \%$ geographically area of the country India with $6 \%$ resident population of the country. It stretches over $2400 \mathrm{~km}$ from east to west and varies in width from 220 to $300 \mathrm{kms}$ in north to south disposition (Agrawal et.al., 1997). Modern geo-informatics tools such as Remote Sensing (RS) and Geographic Information System (GIS) are increasingly used for landslide problem investigations (Van Western, 1996; Van Western et.al., 2000; Dai and Lee, 2002; Krishna, 2002; Krishna, 1999; Krishna, 1997). A combination of information derived from RS data and ground bases field details organized into a GIS core allows various forms of analysis methods (Van Western and Terlien, 1996; Krishna, 2000). The shortening in the Himalayan fold- thrust belt (FTB) accounts for a significant portion of this convergence, and is dominantly accommodated by a system of south-vergent thrust faults, where early large displacement faults are often folded by continuing deformation (Medlicott, 1864; Heim and Gansser, 1939; Gansser, 1964; Valdiya, 1980; Srivastava and Mitra, 1994; Ray, 1995; Pearson and DeCelles, 2005). The young cones came into existence after the rejuvenation as geomorphic features related to slope adjustment leading to the present day landscape. With the adjustment of hill slope, materials of the alluvial cones have attained a critical state of equilibrium because their slope corresponds to the angle of response of the cone forming material. Any agency, either human or natural, disturbing this limiting state of equilibrium and the stability would result in sliding of the material. Therefore, these alluvial accumulation levels very along the river valley which can help to understand the problems of slope stability, weathering characteristics, and physiographic changes through the different stages of geomorphic evolution of this Himalayan terrain. Landslides occur frequently in the Himalayan State of Sikkim, India. This is due to the high intensity of rainfall that not only contributes to rapid erosion and weathering of the rock mass, but also increases groundwater levels causing reduction in the stability of natural slopes. These factors, coupled with the increase in human activity associated with urban development, have contributed to increased instability of slopes in the region. The geotechnical investigations carried out in the affected areas indicate that both the overlying soil and the discrete joint surfaces in the bedrock have moved during the landslide activity. Sliding along the discontinuities has occurred because of increased porewater pressure along the joints. Both smooth and rough joints are affected by increased water pressure resulting from high-intensity rainfall. Sliding of the overlying soil is associated with the saturation of soil pores and with formation of shallow and deep subsurface flows that generate pore-water pressure in the materials that form the slopes (Bhasin et.al, 2001). In this mountain terrain the diverse litho-structural set up is being affected by glacial, periglacial and fluvial agencies. The high rugged slopes are being continuously denuded and washed by ice and water, and carried through the channel and stream network. In this process, huge debris and sediments 
are being dumped on way. The litho-structural aspects are dictating the formation of stream pattern and its width and depth. The smaller channels invariably follow the available topo-sheets, but the higher order streams follow the major joint patterns and fault traces in the rock (Chansarkar, 1975). In the valley development, the valley sides slopes are generally very steep and the consequent streams draining them have funnel shaped large catchment in the headwater portion. These streams bring huge debris and deposits as 'alluvial fans' at the confluence, affecting changes in thalweg (river line) of the main river (Chansarkar,1975). The river-transported sediment is deposited in form of number of terrace levels along its course. This type of river terrace is observed along Tista, Rangit, Ramman, Rani khola (locally river is known as 'khola', 'Jhora' and 'chu') and other rivers within their various meandering courses. The Himalayan orogen is considered to have formed at the northern margin of East Gondwanaland (Valdiya, 1997; Goscombe et al., 2006; Yoshida and Upreti, 2006). The growth of the Himalayan orogen is related to the collision of the Indian lithosphere against the Eurasian lithosphere that started with initial impingement at $\sim 52 \mathrm{Ma}$ (Rowley, 1996) and is continuing to the present, and has been in thefocus for several studies including the characterization of collisional orogeny as well as the plate tectonic modeling of the link between mantle dynamics and surface processes (e.g. Santosh and Omori, 2008; Santosh $e t$ al., 2009). The shortening in the Himalayan fold- thrust belt (FTB) accounts for a significant portion of this convergence, and is dominantly accommodated by a system of south-vergent thrust faults, where early large displacement faults are often folded by continuing deformation (Medlicott, 1864; Heim and Gansser, 1939; Gansser, 1964; Valdiya, 1980; Srivastava and Mitra, 1994; Ray, 1995; Pearson and DeCelles, 2005). From north to south the major thrust systems are the Main Central thrust (MCT 1 and 2), the Ramgarh thrust (RT), the Lesser Himalayan duplex (LHD), the Main Boundary thrust (MBT) and the Main Frontal thrust (MFT). Traditionally the MCT and the MBT have been used to mark the boundaries between the Greater- and LesserHimalayan, and the Lesser- and Sub-Himalayan Sequences respectively. Landslides and mass movements are one of the natural catastrophies, always because a major problem in the Uttarakhand Himalayas by killed hundreds of people every year besides damaging the properties and blocking the communication links. Mass movements in the mountainous terrain are natural degradation processes, and one of the most important landscape building factors. Most of the part of the Uttarakhand Himalaya have been subjected to slope failure at least once under the influence of a variety of factors, and triggered by extreme rainfall or earthquake. During the last few years the approach on geo-environmental problems has changed with science trying to come up with satisfactory ways to predict natural disasters rather than trying to take remedial action after a catastrophe. The primary objective is to minimize casualties and economic repercussions and not stop development. Broadly speaking landslides are concerned with a number of parameters such as geology (faults, hydraulic conductivity, and strength), tectonics (discontinuities), seismicity, climate (rainfall), land use, topography, drainage (river), slope/slope aspect and human influence. Indian Himalayan Region (IHR) has one of the most rugged mountain topography in the Himalaya, which is geologically one of the youngest mountain range in the world and geologically still active, with vast wealth of natural resources. The complex is also included in the different states of the atmosphere particularly the meso, macro and microclimates which are important ecological factors. There has been an accelerated pace of construction activities, particularly in the past couple of decades, which often culminate in disproportionate urbanization( Josh et.al., 2003). The functional interactions are formed between geo-environmental factors and their spatial environment. Anthropogenic activities are also causing a major drastic modification in the composition of the ecosystem. The harmonious relationship between man and his environment ensures under the environmental geology1. Therefore, geo-environment can be approached both by geoscience and biological science. Studying the contribution of such diverse geo-environmental parameters for a particular application would certainly enhance our knowledge over the state and dynamics of that site. Hazards due to landslides and mass movements are the common phenomenon in mountain realm like the Himalaya. In the recent year a large number of landslides cause extensive damages to the roads, buildings, forests and agricultural fields in many parts of the terrain and also the ongoing developmental activities expanded towards unstable hilly terrain have aggravated the slope stability. These hazards cannot be prevented in all cases but the impacts can be minimized to a certain extent by taking effective timely measures to cope up with them for disaster preparedness. Within this framework, geology and geomorphology in particular, may play a relevant role in assessing areas at high landslide hazard and in helping to mitigate the associated risk, providing a valuable aid to a sustainable progress (Rawat et.al., 2010). The landslide stabilization measures adopted by local could also be refined as per the changing scenarios so the community may come forward easily. This will save the environmental degradation in the local level and could be great help to Himalayan for conservation (Joshi et.al., 2011). GPS is a very useful tool to be utilized for a wide range of scientific applications. This technology increases the accuracy, productivity, monitoring capability, rapidly and economy with respect to size of the study area and it is often better than classical geodetic survey techniques. This paper evaluates the appropriate GPS technique i.e., Rapid Static and RTK for monitoring the landslide behaviours at Bakthang landslide $(3.5 \mathrm{~km})$. The result indicated that the GPS modern techniques are very reliable for landslide 
monitoring. Using Global Positioning System technology to provide differential position information with sub centimetre level accuracy in structural and land monitoring applications was investigated (Rawat et.al., 2011).

\section{Materials and methods}

The description of study area, data acquisition and methods used for data processing, procedure for preparation of thematic maps and criteria used for identification of LHZ using GIS and Remote Sensing are discussed in this section.

\section{Study area}

The study area lies between the latitude $27^{\circ} 14^{\prime} 20^{\prime \prime}$ and longitude $88^{\circ} 18^{\prime} 15^{\prime \prime}$ E. The total geographical area of the south district of Sikkim is 750 sq.km. and it is the 2 largest populated district next to East District of Sikkim. South District though having a smaller area is more thickly populated. Namchi, the Administrative headquarters of South District, is a small town which is accessible from the neighbouring state of West Bengal. South District offers spell bounding views and excellent Trekking places. Namchi is $90 \mathrm{~km}$., away from Gangtok, the state capital. The type and thickness of soils differs in steep slopes, valley side slopes, valleys and terraces. The barren, steep slope is consisting of shallow and loose textured soil, while densely vegetated areas are having comparatively thick soils that are rich in organic matters. The terraces consist of granular soils and are rich in moisture.

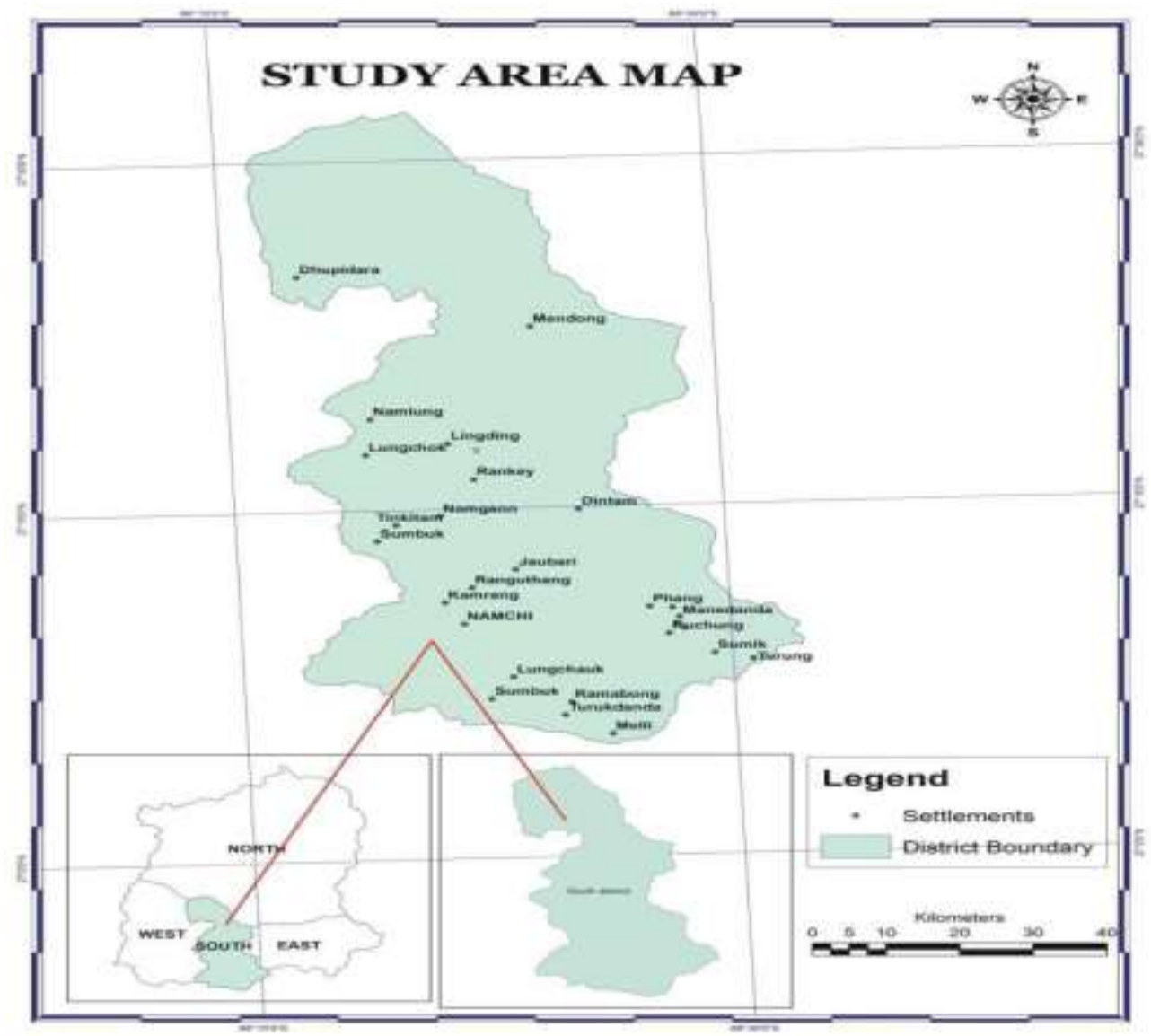

Fig.1 Location map of study area

\section{Data Used}

Following Materials were adopted for this study:

\section{Satellite data:}

IRS LISS-III, LISS-IV and Panchromatic merged data along with Survey of India (SOI) maps on 1:50,000 scale have been primarily used for the preparation of thematic maps covering the area in Sikkim State.

\section{Software Used}

1. Erdas Imagine version. 9.1/9.3 for geo-referencing of scanned maps, digitizing \& creating raster and vector layers. 
2. Arc Info Workstation for editing the layers.

3. ARCGIS 9.3 for modeling and to prepare the layouts.

4. ARCMAP 9.3 for data analysis \& generation of Landslide Hazard Zonation map.

5. ILWIS Academic 3.3 for advance techniques.

\section{Aims and Objectives}

Earlier the mankind had no means to assess the susceptible terrain for its mass movement and accurate mapping of landslides and was a tedious process through conventional mapping techniques. The remote sensing technology has emerged as a powerful tool to map accurately the existing landslide areas, as well as the degree of instability of the terrain. The present study therefore, aims to use the Remote Sensing and Geographic Information System to prepare a landslide map and also to study various terrain parameters for landslide modelling and hazard zonation in the study area.

The main objectives of the study are to utilize the remote sensing and GIS techniques in order to:

* Integration of various parameters to analyze landslide and geo-environmental relation and

* Generation of landslide hazard zonation of South Sikkim using Remote Sensing (RS) and Geographical Information System (GIS).

\section{Drainage}

The drainage of the study area was digitized from Survey of India (1962-63) toposheets i.e., $78 \mathrm{~A} / 6$, $78 \mathrm{~A} / 7,78 \mathrm{~A} / 8$ and $78 \mathrm{a} / 12$.The streams within a drainage basin form certain patterns, depending on the slope of land, underlying rock structure as well as the climatic conditions of the area. These are dendritic and radial patterns (Fig.2). The dendritic pattern develops where the river channel follows the slope of the terrain. The stream with its tributaries resembles the branches of a tree, thus the name dendritic. A river joined by its tributaries, at approximately right angles, develops a trellis pattern. The drainage of the district is controlled by the perennial Tista and Rangit rivers along with their tributaries. Tista the main river passes through the area which originates from the central crystalline zone defined by high mountain ranges which is covered by glaciers. Most of the Kholas have originated from the higher altitudes and flow down by cutting deep gorges in lower altitude where they ultimately join with the main river Tista.

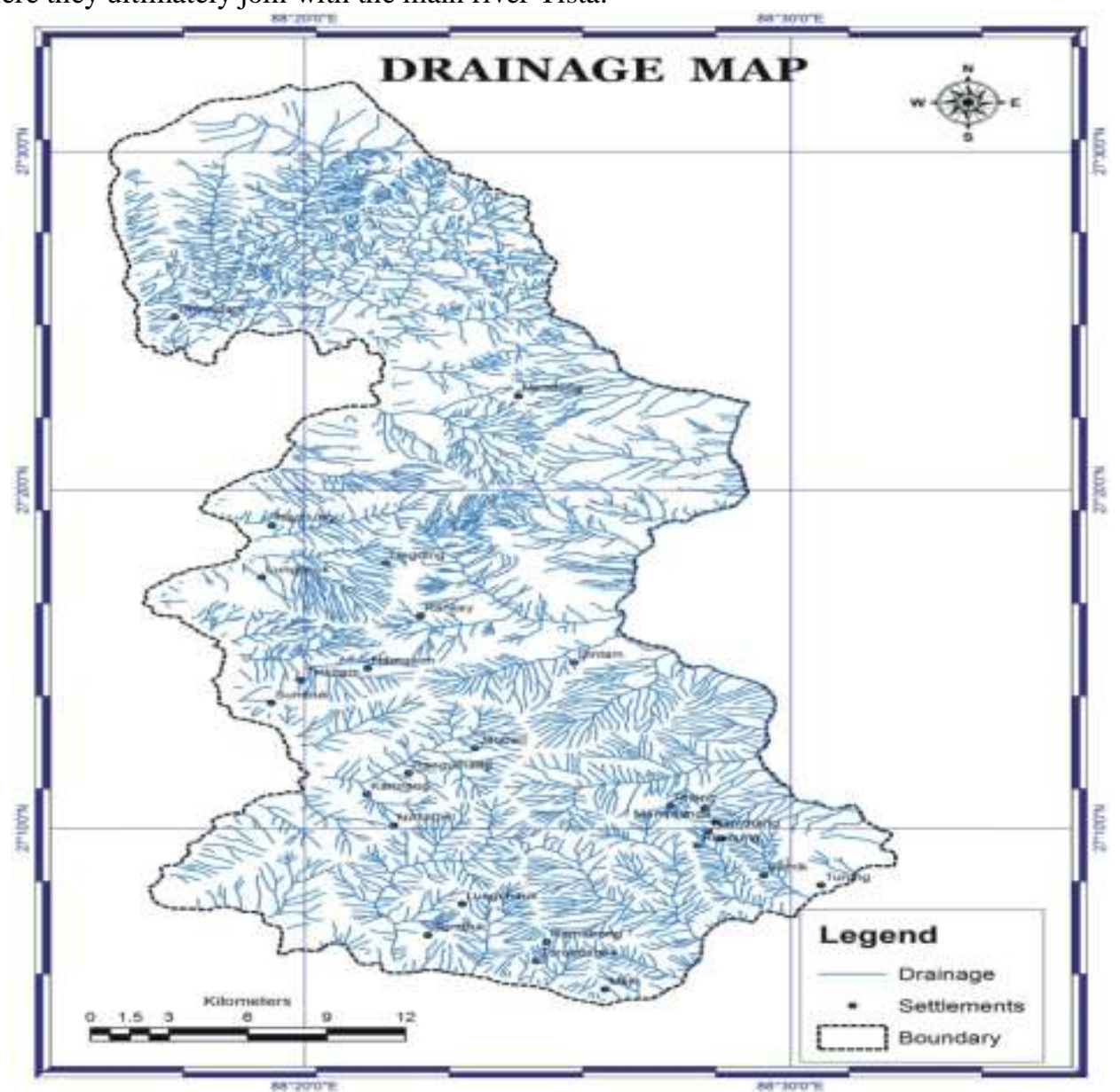

Fig.2 Drainage pattern of the study area 


\section{Drainage Density}

The drainage digitized from Survey of India toposheets i.e., $78 \mathrm{~A} / 6,78 \mathrm{~A} / 7,78 \mathrm{~A} / 8$ and $78 \mathrm{a} / 12$. In the study area each channel with its tributary was identified by topographic maps of Survey of India. The channel lengths were marked by field checks and area calculation was done using Morphometry techniques. The drainage density is an important indicator of the linear scale of landform element in stream eroded topography and defines as the total length of stream of all orders/drainage area and may be an expression of the closeness of spacing of channels (Horton, 1932). The significance of drainage density is recognized as a factor determining the time travel by water (Schumm, 1956). The low drainage density is favoured in regions of highly permeable subsoil material, under dense vegetative cover where relief is low, while high drainage density is favoured in regions of weak or impermeable sub-surface materials, sparse vegetation and high mountain relief (Fig.3).

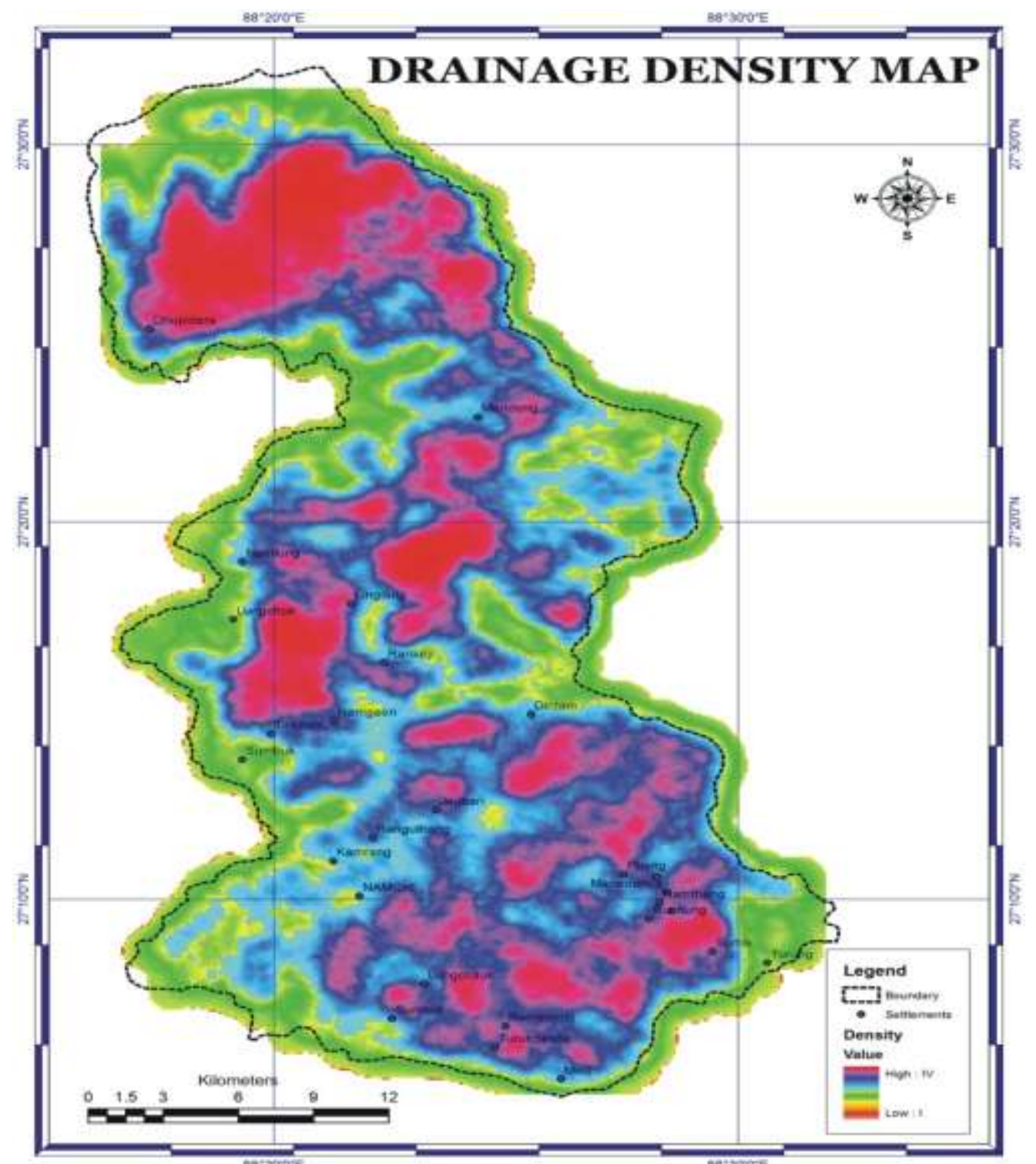

Fig.3 Drainage density map of the study area

\section{Geological set up of the study area}

The geological formation of South Sikkim district comprises Quaternary deposits of alluvium in river terrace which are developed sporadically along the streams and rivers. The Gondwana rocks occur in the South Sikkim area around Namchi. The rock types are shale, sandstone, quartzite, coal. Among the Daling group Buxa formation is younger and consists of quartzites variegated sltates, black sltates and dolomite. Buxa formation is the oldest rock group represented by an alternative sequence of metamorphosed politic-semi-pelitic to psamatic rocks comprising chloritic phyllite semicite phyllite, grey massive quartzite and variegated states (Fig.4). Quartzite, High grade Gneiss, Granulite with bands of botite/Graphite schist with pegmatite and aplite veins. 


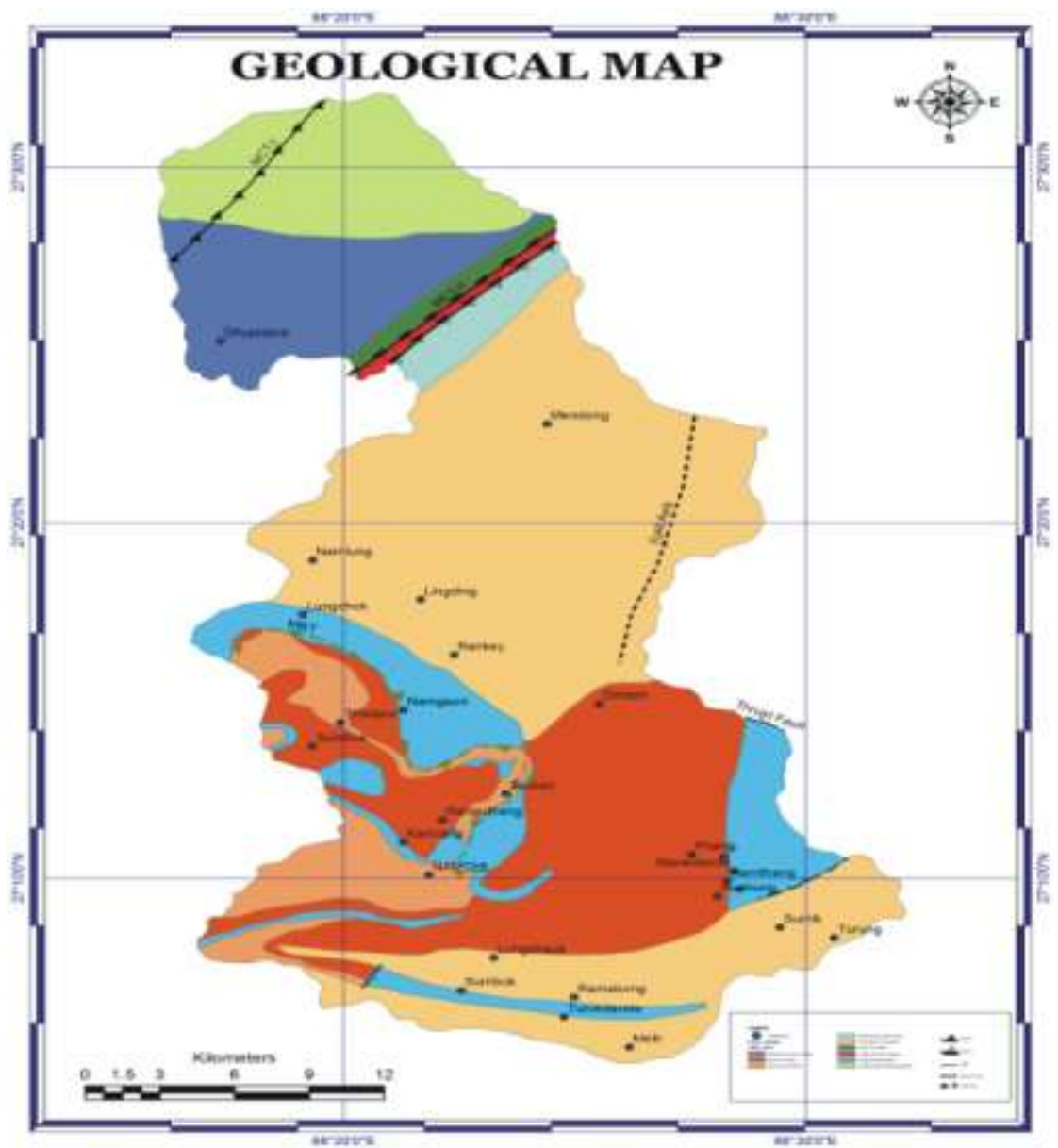

Fig.4 Geological map of the study area

\section{RAINFALL AND CLIMATE}

The average annual rainfall of the south district of Sikkim of the tune of $1422.21 \mathrm{~mm}$ receives in past 2004 to 2010, (7) Years.

\section{Climate}

The climate in the district is in general cool throughout the year. It is very cold during winter months. Summer starts at the end of March and lasts up-to middle of May, when the atmospheric temperature rises to about $20^{\circ} \mathrm{C}$. Monsoon generally sets at the end of June and continuing up to October (Fig.5). Maximum rainfall takes place during the month of June to September. The average annual rainfall is $1422.21 \mathrm{~mm}$.

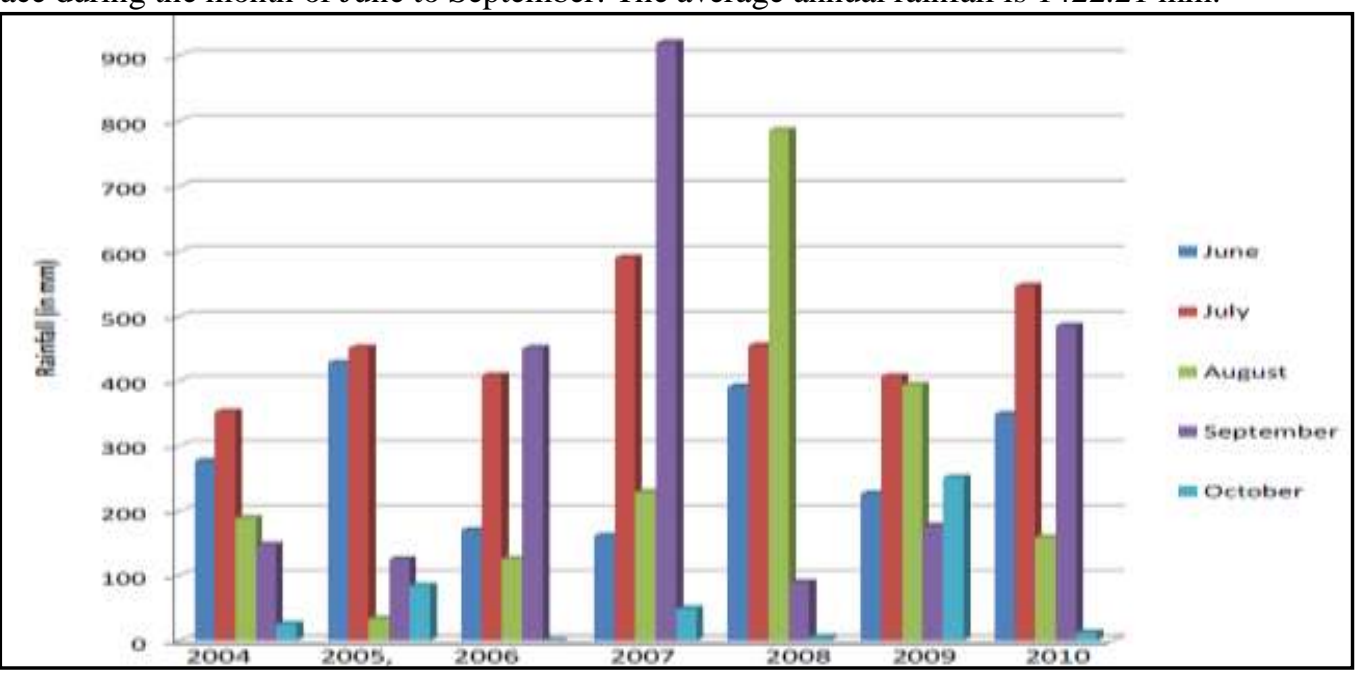

Fig.5 Monthly rainfall of Namthang, South Sikkim 


\section{Geomorphology}

The South District of Sikkim is mountainous forming part of Eastern Himalaya. It is characterized by Himalayan topography with a series of crisscross ridges and ravines. The altitude varies from 230 to $7000 \mathrm{~m}$ above msl. The south district of Sikkim has moderate dissected hill and Valley to Highly dissected valley as well as large number of denudational hill in the region (Fig.6). The State's climatic condition is determined almost exclusively by the difference in altitudes. Most of the rivers and streams in this area are in the boulder stage and have not attained a permanent regime even before entering the plains. While regular meandering courses, deep well defined beds and wide flood plains are the characteristics of stable rivers in the plains, the boulder rivers are having shallow beds and shifting braided and interlaced channels. Urbanization in the road vicinity and also in the catchment areas is one of the major causes inducing unstable conditions, especially surface scour and thereby allowing water to percolate and create pore pressure conditions that cause movement of large scale debris creating blockage. The drainage basin of the present area is fan-shaped and has a greater run-off rate.

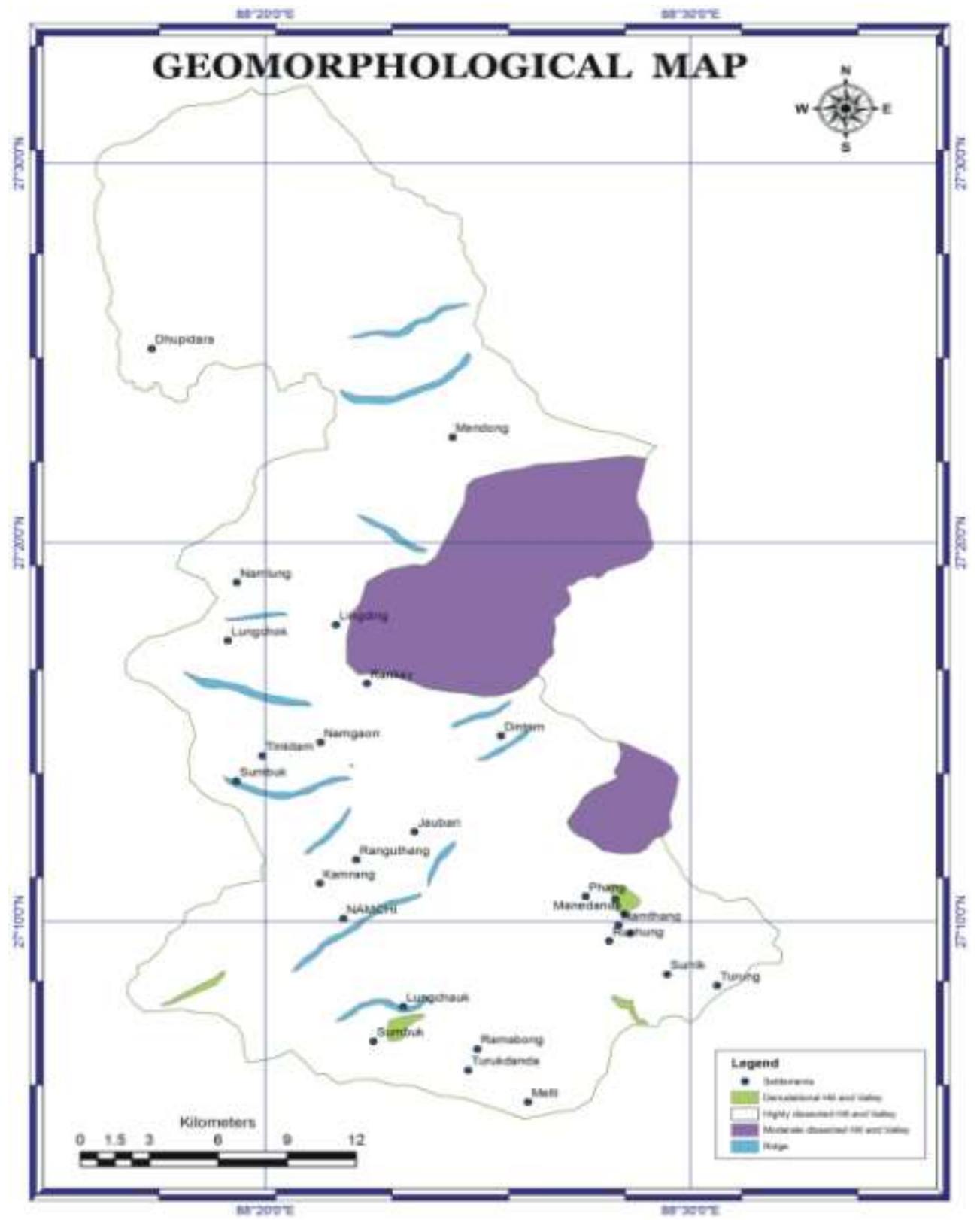

Fig.6 Geomorphological map of the study area

\section{Lineament:}

The photo-lineament map was prepared using polygon mode ARC/INFO environment. The lineament map developed with help of Survey of India Toposheets and IRS-1C LISS III satellite data. 


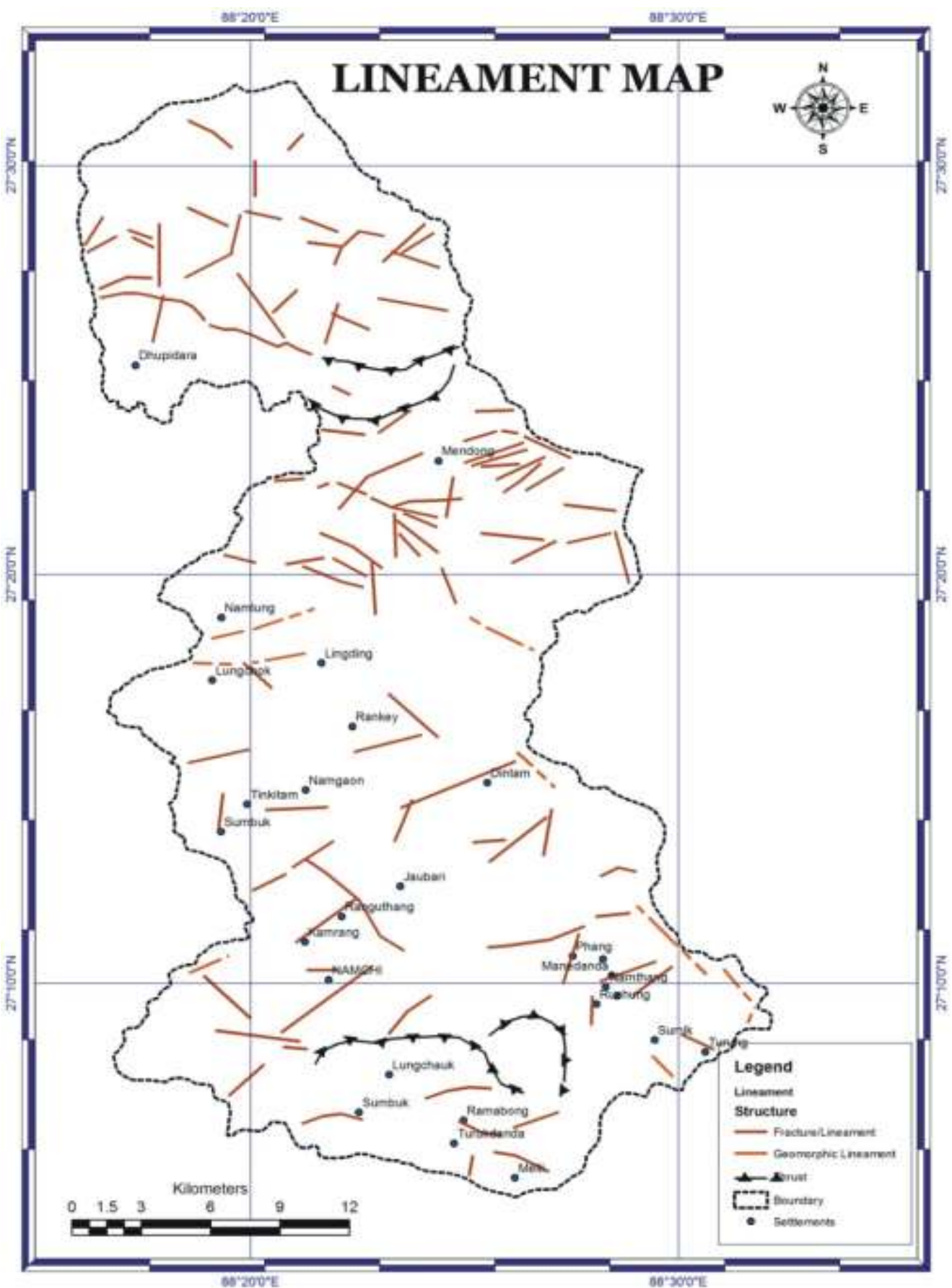

Fig.7 Lineament map of the study area

Fault and lineament maps were prepared from the satellite imagery and by referring to the existing geological information, Lithological map, and drainage pattern, dissection and field observations (Fig.7). Lineaments are mapped as they have possible bearing on slope stability of a region. Based on the type of the weak planes and their lengths, buffer zones are defined for analysis. Several lineaments occur trending almost parallel to each other, implying that the stresses, which produce these features, were not local but acted in a large region to produce a number of failure or weak zones parallel to a particular direction.

\section{Slope Aspect:}

The slope aspect derived from ASTER DEM using RS and GIS techniques.There is some association of landsliding with slope aspect, with a tendency for landslides to develop preferentially on southeast to east facing slopes. 


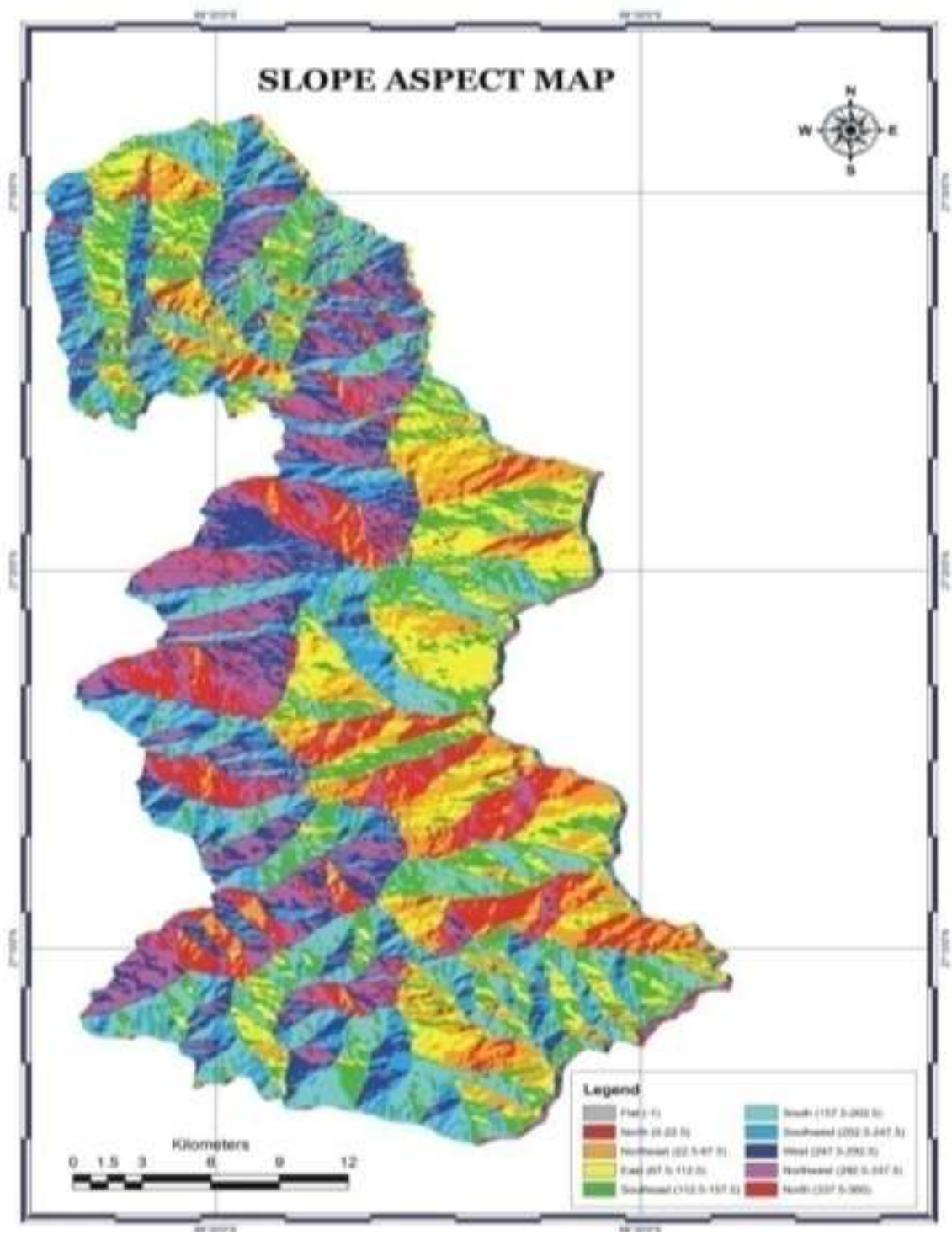

Fig.8 Slope Aspect map of the study area

The number of landslide in these faces SE 12\%, SW 20\%,NW 18\%,W $16 \%$ and South face 24\%.This is consistent with directional trigger mechanism such as intense rainfall from tropical storm that mostly frequent in the study area from ESE or SSE. A reasonable explanation of this pattern may be that slope aspect affects the density of shallow debris slides by limiting the development and thickness of drier slopes. The elevation of study area varies $200 \mathrm{~m}$ to $6000 \mathrm{~m}$ (Fig.8) the slope aspect categories represent the number degrees of east and they increase in counter clockwise that is 90 degree is north, 180 degree is west, 270 degree is south and 360 degree is east. The slope direction in the study area are: North $0-22.5^{0}$, Northeast $22.5-67.5^{0}$, East $67.5-112.5^{0}$,

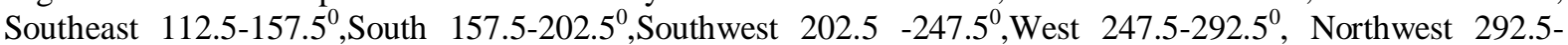
$337.5^{0}$, North $337.5-360^{\circ}$.

\section{Physiography:}

Survey of Indian Toposheets has been taken as spatial database on physiographic features along with the satellite data, Geographic information System (GIS) tools and the ground realities. The strike ridges and valleys are the result of geological structure and lithology. Likewise, steep scarps, peaks and mass wasted scree slopes are the result of denudational processes (Fig.9).

Differential weathering and erosion of various rock types has resulted in such relief variation. The low relief area is basically consisting of weaker rocks like schist and phyllites, while quartzite, gneiss give rise to higher relief with sharp crested ridge because of relatively resistant to weathering and erosion.

Presence of steep scarps, deep narrow valleys, springs, straight course of chhu suggest that the area is still in its youthful stage of geomorphic cycle. The contours were traced from the toposheets, scanned and digitized using software ArcGIS/Arc Info. Digital Elevation Model has been prepared using ASTER 30m DEM. 


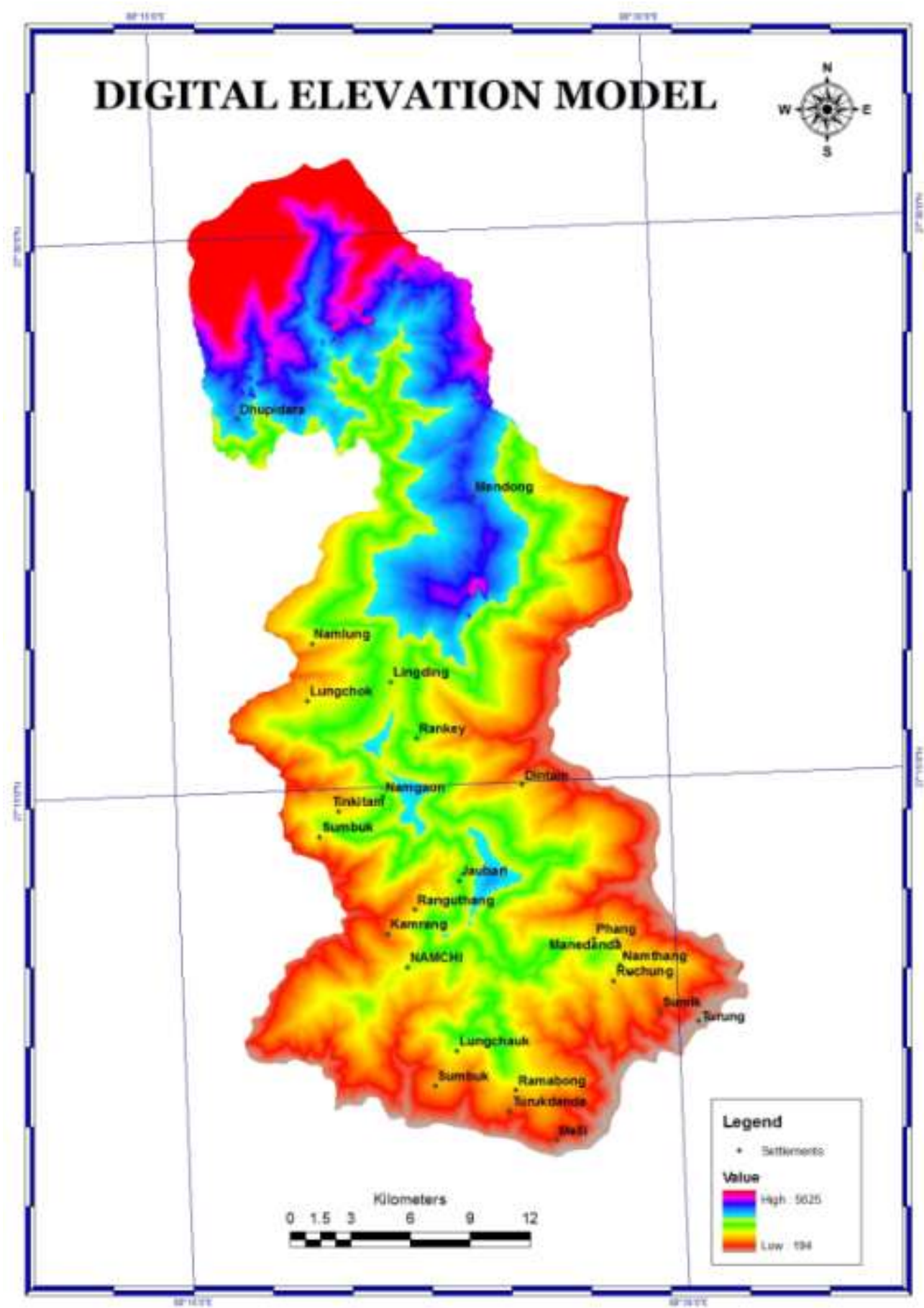

Fig.9 DEM of the study area

\section{Land use/land cover pattern:}

Prominent eight classes of land use / land cover were identified in the study area. Alpine forest, scrub land, mix forest, dense forest, Settlement/Agriculture, snow and moraine are identified in the study area (Fig.10). IRS 1C/1D LISS III bands 2, 3 and 4 were used for interpretation of land use/land cover pattern together with ground- truth checking. Individual bands as digital data were downloaded into the image processing system and image registration, noise removal and enhancement were performed. Apart from making observation on the individual bands, FCC was generated using bands 2, 3 and 4 by assigning blue, green and red combination. Thereafter, interpretations were made on the various land use/land cover classes in the study area by supervised classification technique. An approach of hybrid classification was adopted to overcome the hill shadow problems. 


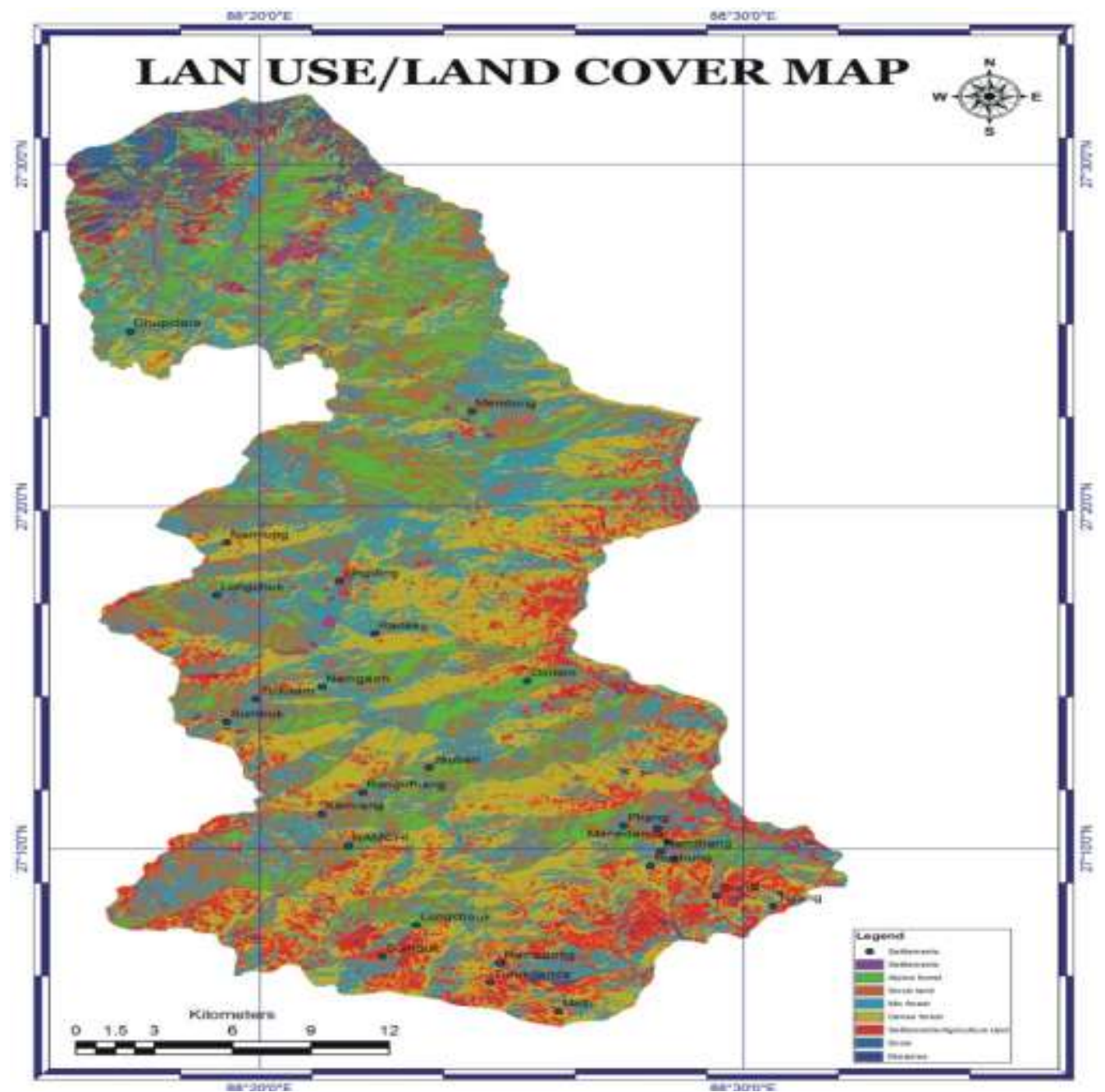

Fig.10 Land use/Land cover map of the study area

\section{Soil characteristics of Sikkim:}

The soils of the district in general have derived from parent rocks such as Sandstone, Phyllite, Schist, gneisses and colluvial materials. Soils are generally acidic to very acidic in reaction having soil $\mathrm{pH}$ between 5.00 and 6.0. Since soils are basically weathered products of the rocks, there is a wide variation in the soil characteristics of Sikkim. According to the National Bureau of Soil Survey, soils of Sikkim are broadly grouped under five physiographic zones (National Bureau of Soil Survey, 1994) (Fig.11) as listed below.

\section{Soils on summit and ridge tops:}

Steeply sloping (> 30\%) surfaces register mostly coarse-grained soils with rock fragments.

Moderately steep sloping (30\%) surfaces exhibit thick soil cover. They are well to somewhat excessively drained, coarse-loamy to fine-loamy soils, with little or no rock fragments. Moderately sloping (15\%) surfaces are composed of well-drained fine-loamy soils with local strewn pebbles on the surface. They are also associated with coarse loamy soils at places.

\section{Soils on side slopes of hills:}

On steeply sloping surfaces (50\%) they are excessively drained coarse-loamy to fine-loamy soils with slight surface stoniness.

\section{Soil on valleys:}

The direct effect of surface drainage and associated landslides has given rise to a wide variety of soil types on moderately sloping to moderately steep sloping banks of the river Rangit in the form of a narrow valley. These are excessively drained loamy-skeletal soils with slight stoniness and moderate erosion.

\section{Soils on cliff and precipitous slope:}

These are excessively drained loamy skeletal soils with strong stoniness and very severe erosion. 


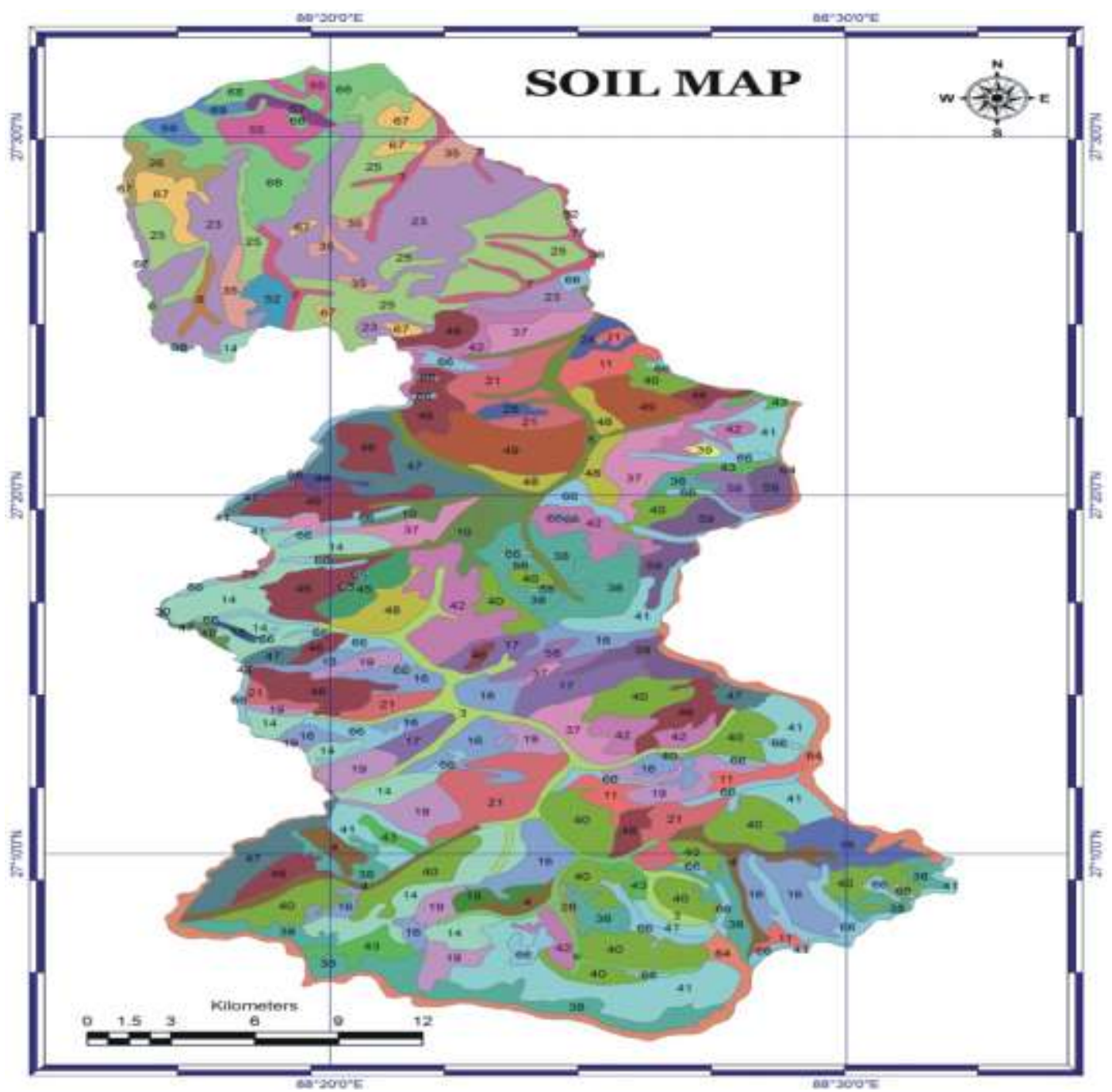

Fig.11 Soil cover map of the study area

\section{Integration of thematic layers and their analysis:}

Remote sensing and GIS based methodology for LHZ is also presented in Fig.12.The weighting-rating system based on the relative importance of various causative factors as derived from remotely sensed data. The causative (instability) factors include surface and bedrock lithology and structure, bedding altitude, slope steepness and morphology, stream evolution, climate, vegetation cover, land use and human activity. The various thematic layers, such as geological map, land use / land cover map, slope map, etc. were arranged in hierarchical order of importance and a weighting number (from 0 to 9) given to each map layer. Each class within a thematic layer was assigned an ordinal rating from 0 to 9 . A summation of these layers was carried out and the cumulative score was regrouped into five classes. Using weighted Overlay and error method the weightrating values have been re-adjusted. The most important direct cause for landslide activity is constituted by thrust-faults, as they signify the area of sheared rocks. Hence, the highest weighting is assigned to thrusts. The hazard of landslide decreases with the increase in the distance from the thrust (buffer). The classes have been assigned a rating in decreasing order with the distance from the thrust. The photo-lineaments are relatively minor features in comparison to thrusts and hence a relatively lower rating is assigned to the each buffer class in comparison to the thrust buffers. The geological formations play a significant role in this area for landslide activity. In the case of soil texture, the landslide-occurrence probability value is higher in rocky sandy loam and sandy loam, and is lower in fine sandy loam, silt loam, gravelly silt loam, and loam. The various land use / land cover classes considered in this study were Alpine forest, scrub land, mix forest, dense forest, Settlement/Agriculture, snow and moraine. The settlement (least vegetated) areas are the most prone to landslide activity, and hence highest rating is given to this class. As vegetation density increases the stability of slope tends to increase, hence ratings were given accordingly. The slope-angle is also a very important parameter in landslide activity. In this area, the slopes were divided into five classes and accordingly ratings to the slope categories were assigned. 


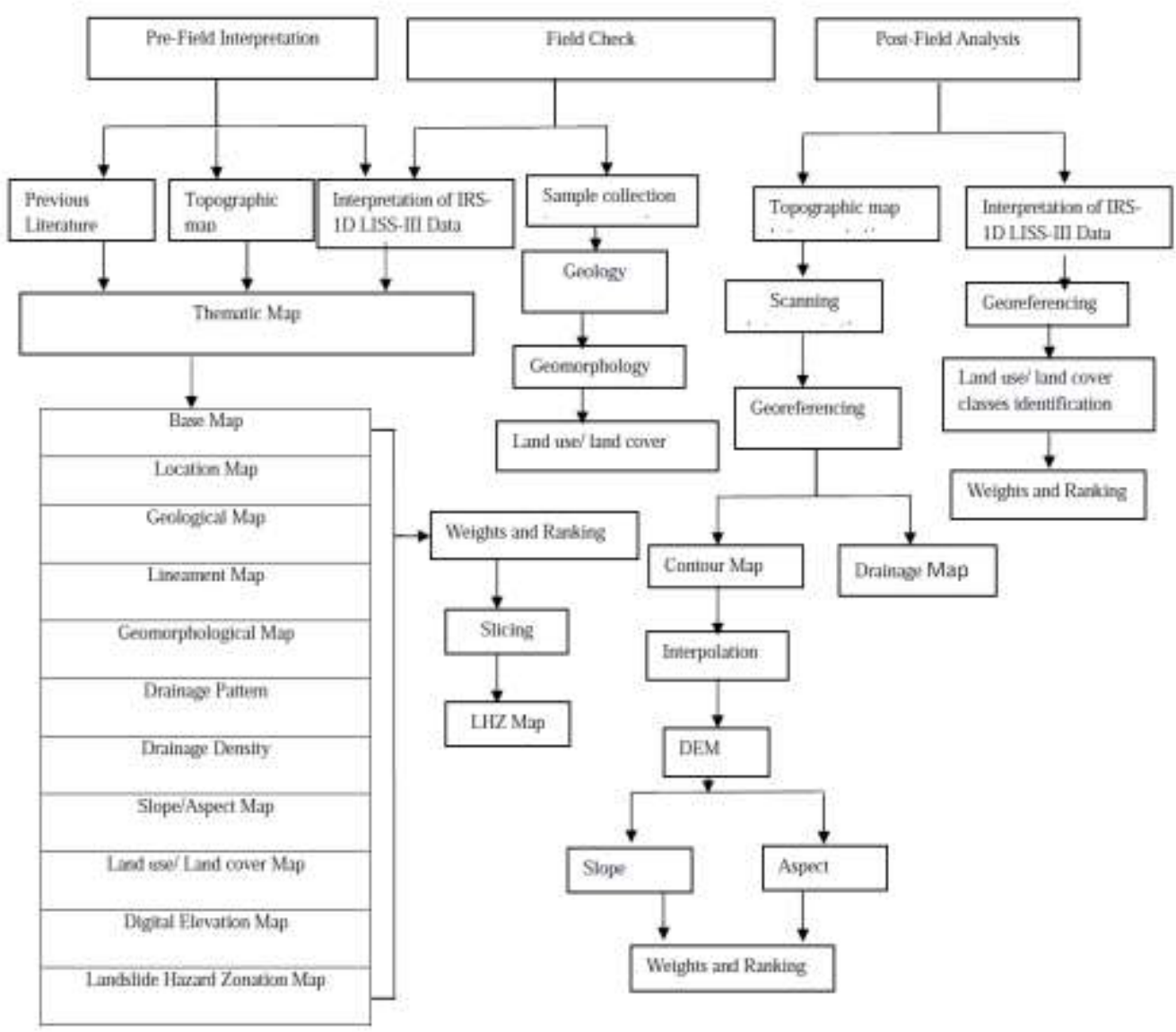

Fig.12 Methodology used for Landslide Hazard Zonation

\section{Landslide Hazard Zonation Map:}

Hazard indicates the probability of occurrence within a specified period of time and within a given area of a potentially damaging phenomena e.g. a landslide. 'Landslide hazard/susceptibility zonation' refers to the division of a land surface into homogeneous areas or domains and their ranking according to the different degrees of actual/potential hazard caused by the mass-movement. In the recent past, various methods and techniques have been proposed to analyse the causative factors of landslides and produce maps-portraying the probability of occurrences of similar phenomena in future. Broadly these methods can be classified as direct and indirect methods. The direct method consists of geomorphological mapping wherein, the past and present landslides are identified and assumptions are made on the factors leading to instability, following which, zonation is made of those sites where failures are most likely to occur. The indirect method includes two different approaches, namely, the heuristic (knowledge driven) and statistical (data driven) techniques. In the heuristic approach, Factors influencing landslides, such as rock type, slope, landform, landuse etc. are ranked and weighted accordingly to their assumed or expected importance in causing mass movements. This is normally based on 'apriori' knowledge available to the experts on various causes of landslides in the particular area of investigation. In the present study, a combination of expert opinion and statistical technique has been used to arrive at weightages, for landslide Hazard Zonation. Risk means the expected number of lives lost, persons injured, damage to properly, or disruption of economic activity because of particular natural phenomenon. Vulnerability means the degree of loss to a given element (or set of elements) at risk resulting from the occurrence of a natural phenomenon of a given magnitude. Basically terrain is analyzed with respect to various geo-environmental factors and each factor or theme is divided into number of classes. Then each theme and each class is evaluated according to their influence factor on causing landslide. Then finally all the themes are integrated using certain mathematical formulae to prepare the zonation map. This Hazard map is grouped into several classes of probability i.e., very high, high, moderate, low and very low (Fig.13). Hazard maps aim to predict where failures are most likely to take place without any clear indication of when they will take place. However these hazard maps can be use as a guide for future development of infrastructures, settlements and any other construction to avoid future disasters. 


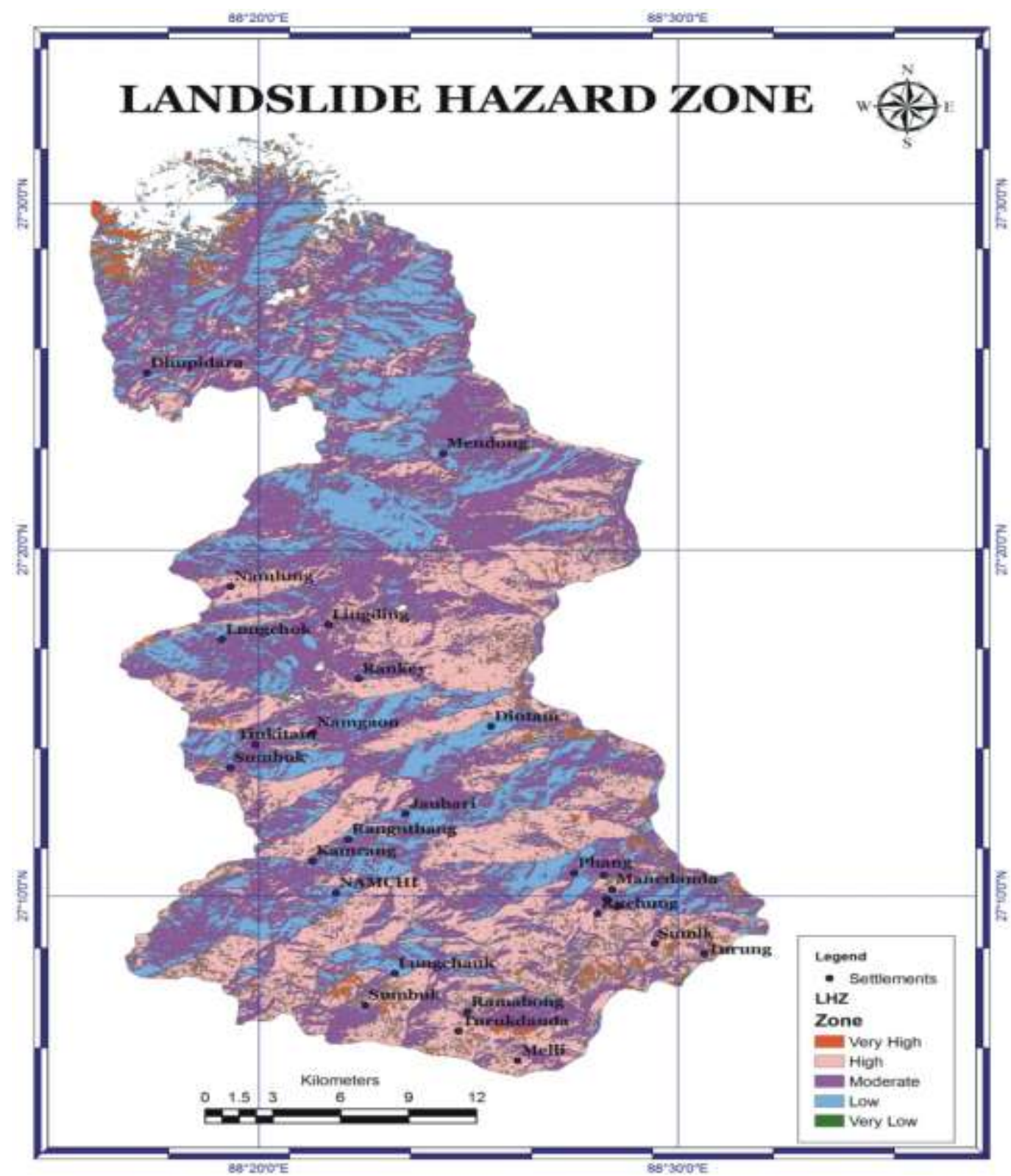

Fig.13 Landslide Hazard Zonation map

\section{Discussion:}

It is clear that urban development in the vicinity of Sikkim State has altered the nature and topography of the ground surface, resulting in adverse human activities that have contributed to slope instability. These activities include excavation works for roads, buildings, embankments, and drainage works, to name a few. It should be noted that landslides of natural undisturbed slopes have also been observed in Sikkim. In natural slope areas, too, it is important to construct drainage systems for collecting water so that movement on the slopes can be reduced. Socioeconomic losses due to landslides in the region are great. Although reliable estimates of the total costs of landslides for a relatively large geographical entity such as Sikkim are difficult to obtain, it will, however, be prudent to categories the economic losses in terms of direct and indirect costs following the examples given by Schuster (1996).

\section{Conclusion:}

Results focussed on Identification of critical Landslide Hazard Zone in the south district of Sikkim, India. This also highlights the importance of multidisciplinary studies of landslides hazards, combining subjects as diverse as geology and geomorphology, Remote Sensing and GIS. Following specific conclusions are drawn from the study: 
1. The overall land use / land cover classification accuracy of the satellite data was 88.48 percent.

2. The distribution of landslides is largely governed by the combined effect of various geo-environmental conditions such as proximity $(<500)$ to the thrust zone, Lingtse granite gneiss, Buxa formations.

3. The high susceptibility to landslides of the south district is mainly due to a complex geological setting combined with contemporary crustal movements, varying slopes and aspect, heavy rainfall, along with everincreasing human interference in the ecosystem.

4. "Landslides pose serious threat to human settlements and structures used for transportation, natural resources management and tourism. It imparts significant damages to property, highway, waterways and pipelines. The slide events were reported to have triggered mainly by rainfall, earthquake and human activities.

\section{Acknowledgement:}

The authors gratefully acknowledge the technical help provided by Director, Uttarakhand Space Application Centre, Dehradun in carrying out this study. First author of the paper is extremely thankful to Dr. Varun Joshi, GGS Indraprastha University Delhi for help me this research work. The authors would also like to thank the local people of Sikkim for useful suggestions, which led to a substantially improved manuscript.

\section{References:}

[1] Agrawal, D.K.; Krishana, A.P.; Joshi, V.; Kumar, K. and Palni, L.M.S.(,1997). Perspectives of Mountain Risk Engineering in the Himalayan region. Gyanodaya Prakashan(Publisher), Nainital, 244p.

[2] Bhasin, R., Grimstad, E., Larsen , J., Dhawan ,A. K. , Singh, R. , Verma ,S.K., Venkatachalam ,K.,(2002). Landslide hazards and mitigation measures at Gangtok, Sikkim Himalaya.

[3] Chansakar, R.A.,1975. Geologic and geomorphic factor in landslide investigations. In : Proc. Seminar on Landslide and toe-erosion Problems with Special Reference to Himalayan Region. Indian Society of Engineering Geology and Government of Sikkim, Gangtok,pp.65-69.

[4] DeCelles, P.G., Robinson, D.M., Zandt, G., (2002). Implications of shortening in the Himalayan fold-thrust belt for uplift of the Tibetan Plateau. Tectonics 21, 1062.

[5] Gansser, A. (1964). Geology of the Himalayas. Interscience, Wiley, New York, 1-289.

[6] Horton, R.E.,1932. Drainage basin characteristics. Trans. Am. Geophys. Union 13: 350-360.

[7] Joshi, V. and Krishana, A.P.,( 2000). Control measures for soil erosion, landslides and debris flow in Hindu-Kush Himalayan belt of Peoples Republic of China. Indian Journal of Soil Conservation, 28 (1), pp.1-6.

[8] Joshi. V., Rawat, M.S.,Sharma, A.K., Kumar.K(2011). Traditional knowledge of natural disaster mitigation and ethno medicine practices in Himalaya with special reference to Sikkim. Indian Journal of Traditional Knowledge Vol. 10 (1), January 2011, pp. 198-206.

[9] Krishana, A.P. and Kundu, S., (2003). Landslide Hazard-A perspective from Sikkim Himalaya. In: Basu, S.R.(editor). Changing Environmental Scenario of the Indian Subcontinent. ACB Publication(publisher), Kolkata,pp.366-389.

[10] Medlicott, H.B., (1864). On the geological structure and relations of the southern portion of the Himalayan ranges between the Rivers Ganges and the Ravee Memoir Geological Survey of India 3, 102.

[11] Mehotra, G.S.; Sarkar, S. and Kanungo, D.P., 1993. Lithotectonics evaluation of landslide and mass movements in GarhwalKumaon Himalaya. Journal of Engineering Geology, vol. XXII, nos.3\&4,pp. 19-33.

[12] Mehrotra, G.S., Sarkar, S., Kanungo, D.P., Mahadevaiah, K., (1996). Terrain analysis and spatial assessment of landslide hazards in parts of Sikkim Himalaya. J. Geol. Soc. India 47, 491-498, April.

[13] Rawat, M.S., Joshi. V., Rawat, B.S., and Kumar, K (2011). Landslide movement monitoring using GPS technology: A case study of Bakthang landslide, Gangtok, East Sikkim, India. Journal of Development and Agricultural Economics Vol. 3(5), pp. 194-200.

[14] Rawat, M.S., Joshi. V., Sharma, A.K., Kumar.K., Sundriyal. Y. P (2010). Study of landslides in parts of Sikkim Himalaya. Indian Landslides Vol. 3 No.2, pp 47-54.

[15] Ray, S.K., (1995). Lateral variations in geometry of thrust planes and its significance, as studied in the Shumar allochthon, Lesser Himalayas, eastern Bhutan. Tectonophysics 249, 125-139.

[16] Rowley, D.B., (1996). Age of initial collision between India and Asia: a review of stratigraphic data. Earth and Planetary Science Letters $145,1-13$

[17] Santosh, M., Maruyama, S., Sato, K., (2009). Anatomy of a Cambrian suture in Gondwana: Pacific-type orogeny in southern India? Gondwana Research 16, 321-341.

[18] Santosh, M., Omori, S., (2008). CO2 windows from mantle to atmosphere: models on ultrahigh-temperature metamorphism and speculations on the link with melting of snowball Earth. Gondwana Research 14, 82-96.

[19] Schumm, S.A.,1956. Evolution of drainage system and slope in badlands of Perth Amboy, New Jersey. Bull.Geol.Soc.Am. 67: 59746.

[20] Srivastava, P., Mitra, G., (1994). Thrust geometries and deep structure of the outer and Lesser Himalaya,Kumaon and Garhwal (India): implications for evolution of the Himalayan fold-and-thrust belt. Tectonics 13, 89-109.

[21] Valdiya, K.S., (1980). Geology of the Kumaon Lesser Himalaya. The Himachal Press, Wadia Institute of Himalayan Geology, Dehra Dun, 1-219.

[22] Van Western, C.J. and Terlien, M.T.J.,1996. Deterministic landslide hazard analysis in GIS- A case study from Manizales(Colombia). Earth Surface Processes and Landforms, vol.21,pp.853-868.

[23] Van Western, C.J.,1996. GIS in landslide hazard mapping, Kakani area, Nepal. Regional training on landslide hazard management and control in the Hindu Kush-Himalayas. May14 to June7, 1996, ICIMOD, Kathmandu, Nepal,95p.

[24] Van Western, C.J.,1997. Statistical landslide hazard analysis. In ILWIS 2.1 for Windows, Application Guide. ILWIS Department, ITC, Enschede, The Netherlands,pp.73-84.

[25] Van Western, C.J.; Soeters, R. and Sijmonos,K.,2000. Digital geomorphological landslide hazard mapping of the Alpago area, Italy. International Journal of Earth Observation and Geoinformation,vol.2, Issue 1,pp.1-10. 